\title{
Jornalismo de proximidade em um mundo conectado
}

DOI: $10.1590 / 1809-58442016313$

\section{Marcelo de Oliveira Volpato}

(Universidade Metodista de São Paulo, Escola de Comunicação, Educação e Humanidades. Programa de Pós-Graduação em Comunicação Social - São Bernardo do Campo - SP, Brasil)

JERÓNIMO, Pedro. Ciberjornalismo de proximidade: redações, jornalistas e notícias online. Covilhã, Portugal: Editora LabCom.IFP, 2015.532p.

Demoramos, mas, enfim, aceitamos a ideia de que o processo noticioso, de fato, passa por transformações, em grande medida por atuação de um conjunto de tecnologias e conexões móveis existentes, hoje. E uma obra capaz de se debruçar de forma profunda sobre este recente movimento já seria de grande relevância. Todos nós sabemos que o campo da Comunicação está diante de um desafio frente às novas culturas, às convergências, à liquidez, à impermanência.

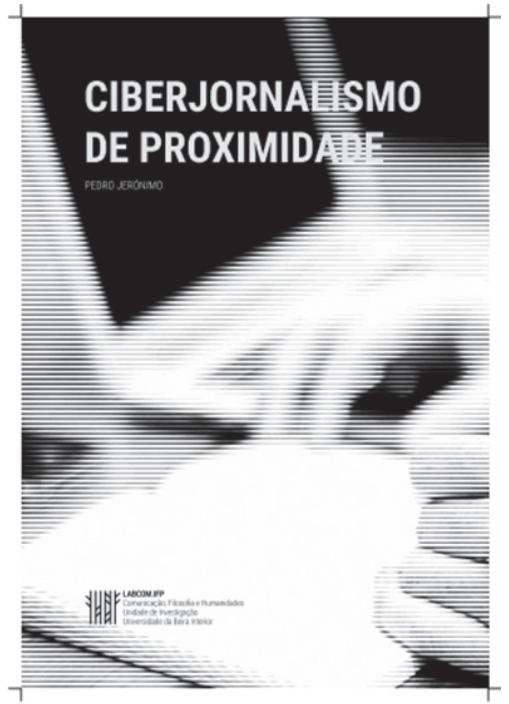

Não obstante, Pedro Jerónimo, autor de Ciberjornalismo de proximidade: redações, jornalistas e notícias online, publicado pela editora portuguesa LabCom.IFP, resolve ir além ao trazer tal discussão para o jornalismo de proximidade, tema que vez ou outra é relegado ao status de jornalismo artesanal, interiorano e amador. Ao contrário, fato é que, segundo dados recentes de Amy Schmitz Weiss, 66\% das pessoas buscam informações e notícias locais pela internet, em seus smartphones.

O livro chega no momento em que muito se fala sobre os fluxos alternativos de informação e comunicação. Mais do que nunca, diferentes possibilidades para criação de conteúdo midiático surgiram, contribuindo para romper com a lógica linear e incentivando a existência de inúmeros emissores. Quão visionários foram Luis Ramiro Beltrán, Juan Diaz Bordenave e tantos outros.

Mas, que informação o leitor privilegia em um mar de dados vindos de múltiplas fontes? Já não é novidade que ele se interessa por aquilo com o qual se identifica e que lhe soa familiar, contexto em que se encontra o jornalismo regional. 
Assim, o livro, resultado de tese de doutorado defendida na Universidade do Porto, em 2013, é um convite à reflexão acerca do ciberjornalismo na imprensa regional de Portugal, perpassando sua origem, contexto, trajetória e produção, que, por fim, resultou em um estudo dos casos Reconquista.pt, OMirante.pt e RegiaoDeLeiria.pt.

A principal questão colocada por Jerónimo está relacionada aos tipos de conteúdos produzidos pela imprensa regional no âmbito do ciberjornalismo. De fato, ele mostra ter uma certeza desde o início de seu caminho pelo conhecimento. $\mathrm{O}$ autor considera que, para melhor entender as rotinas produtivas da imprensa de proximidade, não basta meramente descrever seus aspectos técnicos, mas implica um acompanhamento do cotidiano deste profissional, que, por sinal, chega a partilhar o mesmo espaço físico ou simbólico de seu público.

De linguagem clara, mas sem deixar de lado o rigor científico, a obra está organizada em sete capítulos. De início, ela aborda a saga da produção de notícias em rede, situando as relações entre os fluxos de conteúdos globais e também aquele relacionado ao que acontece logo ali no final da rua. Em seguida, os contextos da imprensa regional entram em cena, em particular a realidade da Europa e de Portugal. Há também espaço para uma longa discussão sobre a imprensa regional, o jornalismo de proximidade e, claro, as notícias online e o ciberjornalismo. Encerra-se abordando os resultados encontrados nos casos estudados, levando em conta, principalmente, as configurações da redação, o perfil dos jornalistas e, por fim, as rotinas de produção.

A metodologia, como não poderia deixar de ser em um trabalho deste teor, também é suficientemente detalhada pelo pesquisador. $\mathrm{Na}$ tentativa de justificar suas trilhas metodológicas, ele também apresenta uma contextualização de como outras pesquisas conseguiram lograr êxito ao se apropriar de tais métodos. Grosso modo, Jerónimo divide seu trabalho em duas etapas: a de um estudo prévio, com um levantamento cronológico dos ciberjornais regionais de Portugal e suas condições de aproveitamento das potencialidades da internet; e a dos estudos de casos, agora por meio de observação participante, entrevistas e questionários, com foco nos três casos já citados.

Entre seus apontamentos, o autor percebe que, por diferentes motivos, os jornais pesquisados negligenciaram as possibilidades que as redes, a internet e até os aparelhos móveis trouxeram, nos últimos tempos. Não que, com isso, ele tenha descoberto a pólvora, mas de forma dialética, Jerónimo insere tal questão dentro da complexidade do modus operandi da empresas de comunicação local e regional e dos jornalistas que nelas atuam.

Neste sentido, a obra também é um ponto de partida, ao enumerar diferentes aspectos ainda a serem melhor aprofundados. Hoje, o mercado de trabalho já começa a receber profissionais que nasceram após o surgimento da internet. Em certa medida, trata-se de uma geração que, em tese, traz uma visão diferente ao processo do fazer-comunicação. Da mesma forma, e seguindo o mesmo raciocínio, também está a audiência. 
Sem querer promover especulações premonitivas, mas apenas considerando a riqueza de dados e articulações que a obra oferece, bem como das atualizações teóricoconceituais que tece e dá vazão, pode-se dizer, com segurança, que estamos diante de uma leitura que se tornará, em breve, obrigatória para os estudantes do tema. Assim, fica difícil não compará-la aos escritos de Carlos Camponez, outra referência publicada nos idos de 2002, também em Portugal.

Quem consulta estas duas obras, a nosso ver, complementares, se vê diante de um fenômeno de comunicação que, mais uma vez, parece ressurgir. Tal como a fênix da mitologia grega, após ter seu fim decretado por renomados cientistas e mesmo frente à forte atuação das tecnologias móveis e ubíquas, a comunicação de proximidade adquire novo alento e possibilidades. Quem, hoje em dia, não consulta em seu celular um conteúdo geolocalizado, relacionado ao local em que está? Por enquanto, a pergunta que se faz é centrada no motivo pelo qual a grande maioria dos veículos de mídia ainda não se despertou para esta tendência.

\section{Marcelo de Oliveira Volpato}

Jornalista pela Universidade de Marília, é mestre e doutorando em Comunicação Social pela Universidade Metodista de São Paulo e membro do Núcleo de Estudos de Comunicação Comunitária e Local - COMUNI, vinculado ao Póscom/UMESP. E-mail: volpatomarcelo@gmail.com 